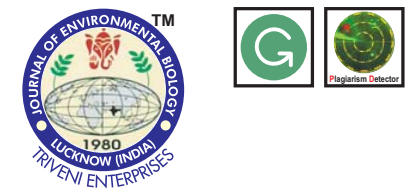

DOI : http://doi.org/10.22438/jeb/38/6(SI)/03

ISSN: 0254-8704 (Print) ISSN: 2394-0379 (Online) CODEN: JEBIDP

\title{
Effect of organic and inorganic turbidity on the zooplankton community structure of a shallow waterbody in Central Mexico (Lake Xochimilco, Mexico)
}

\section{Authors Info}

M.A. Gayosso-Morales', S. Nandini ${ }^{2 *}$, F.F. Martínez-Jeronimo ${ }^{\prime}$ and S.S.S. Sarma ${ }^{2}$

${ }^{1}$ Instituto Politécnico Nacional. Escuela Nacional de Ciencias Biológicas. Posgrado en Ciencias Quimicobiológicas, Carpio y Plan de Ayala S/N, Mexico City 11340 , Mexico

${ }^{2}$ Laboratory of Aquatic Zoology, National Autonomous University of Mexico, Campus Iztacala, Av. de Los Barrios No.1, AP 314, 54090, Los Reyes, Tlalnepantla, State of Mexico, Mexico

*Corresponding Author Email : nandini@unam.mx

Key words

Cyanobacteria Shallow lakes

Species diversity turbidity

Publication Info Paper received: 30.11 .2016 Revised received : 03.02.2017 Re-revised received : 27.02 .2017 Accepted: 06.03.2017

\section{Abstract}

Aim: Lake Xochimilco is shallow $(<2 \mathrm{~m})$ water-body in Mexico City consisting of several interconnected canals. It is now eutrophic, with high levels of turbidity as a result of suspended sediment and phytoplankton blooms. We selected two sites, the Rowing channel with organic turbidity due to cyanobacterial blooms and the Main channel with inorganic turbidity from re-suspended clay. The aim of this work was to present data on zooplankton dynamics in two channels of the lake over one year (June, 2013 to May, 2014).

Methodology: We collected zooplankton by filtering $80 \mathrm{~L}$ of water from two sites in each of the canals, as well as measuring temperature, $\mathrm{pH}$, conductivity, dissolved oxygen, nitrate- $\mathrm{N}$ and phosphate-Ps, Chlorophyll-a, and Secchi disk transparency at each of the sites.

Results: The zooplankton community was dominated by rotifers; cladocerans and copepods were few. The common rotifer genera in thelake were Keratella, Brachionus, Polyarthra, Trichocerca, Filinia, Asplanchna chydorid cladocerans like Chydorus sphaericus, Pleuroxus varidentatus, Alona sp. and copepods Acantho cyclops americanus and Microcyclops rubellus. The canonical correspondence analysis (CCA) in the Rowing channel station, showed that the first two ordination axes explained $46 \%$ of the variance of the species data in CCA. The first and second axes were well correlated with the environmental data. The Monte Carlo permutation test was significant on the firstaxis.

Interpretation: Our study showed that the presence of organic turbidity as observed in the rowing channel had a greater adverse effect than the inorganic turbidity on zooplankton density and diversity.

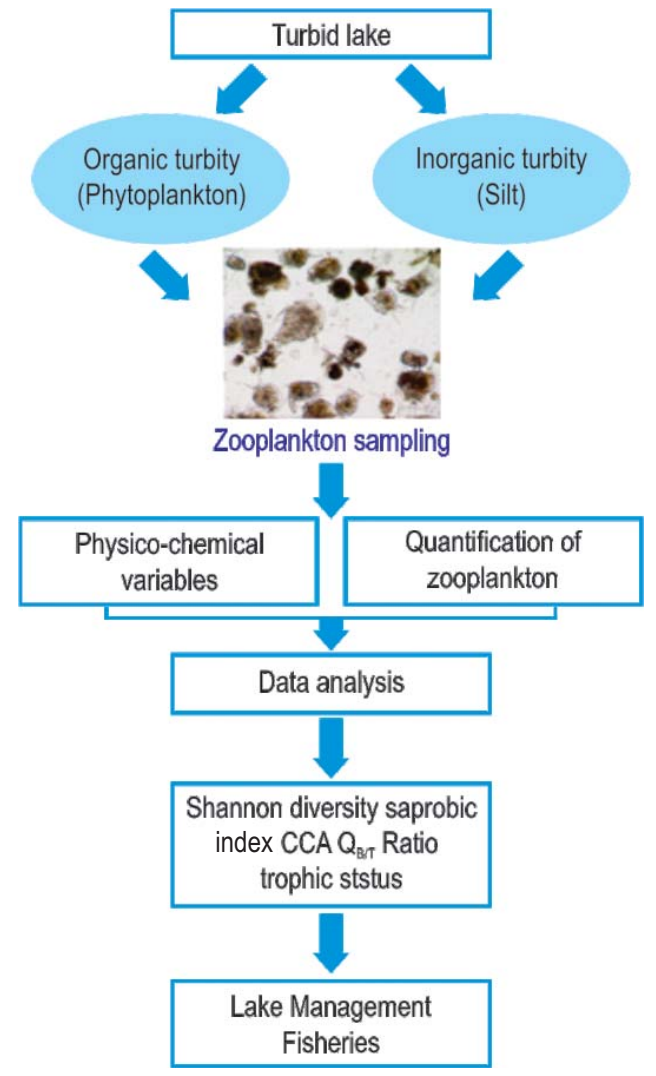




\section{Introduction}

Shallow lakes are often turbid. The turbidity could be due to re-suspension of inorganic sediment (Lövstedt and Bengtsson, 2008), or organic produced by high phytoplankton density or cyanobacterial bloom, which is characteristic of many shallow lakes (Descy et al. 2013). The turbid state, due to high densities of phytoplankton, results in poor water quality and fewer species (Declerck et al., 2005). Cyanobacterial blooms such as those of Microcystis spp. result in low visibility in the water column and have an adverse effect on the feeding and mate searching behavior in visual organisms (Vasconcelos, 2006). Some strains of these surface blooms produce toxins that are harmful to zooplankton, fish, birds, cattle, pets and even humans (Huisman et al., 2005). Turbidity also occurs when sediment and organic matter is re-suspended which serves as food for microorganisms and zooplankton (Donohue and Garcia-Molinos, 2009). Detritus and fine sediments may interfere with the filtering and food gathering processes for several zooplankton species (Kirk, 1990). Extended or frequent sediment re-suspension may result in less energy transfer from lower to upper trophic levels and alteration of the community structure (Levine etal., 2005).

Lake Xochimilco, an ancient natural waterbody in Mexico City, is a product of centuries of land use management resulting in 207 miles of canals, eight small lakes and two seasonal wetlands. Originally it was fed by natural springs and rain water but now the level is maintained with partially treated waste water (MartínezArroyo and Jaurregui, 2000). The lake also supports an intricate network of floating agricultural plots on islands called Chinampas, which were developed by the Mexican tribes in the fourteenth century. Fertilizers and pesticides constantly enter the system from these fields thus increasing the problems associated with eutrophication. The entire ecosystem is in the UNESCO World Heritage List since 1987 and is on the list of International Convention on Wetlands (RAMSAR) since 2004; it is also an area with high human population densities, which gives it a high environmental and socioeconomic value.

The canals in Xochimilco are shallow, $<1 \mathrm{~m}$ in depth for most part. Previous studies demonstrate that this waterbody supports extremely high densities and diversity of rotifers (Nandini et al., 2005: Enriquez et al., 2009), and a low density of microcrustaceans, especially cladocerans, probably as a result of high fish predation pressure on large zooplankton in the system. The dominant fish species include Cichlids (Oreochromis sp.), Cyprinids (Cyprinus carpio) and Poecilids (Xiphophorus helleri). Annually, several tons of the exotic tilapia and common carp are fished out from the lake; close to 7.5 tons per week were harvested over a period of several months between 2006 and 2008 (Zambrano and Valiente, 2008). These high densities of fish have driven the native Axolotl, Ambystoma mexicanum, to the brink of extinction (Chaparro-Herrera et al., 2011). Fish also exert a high predation pressure on cladocerans and thus decrease the interference competition on zooplankton (Kirk and Gilbert, 1990). In turbid lakes, high predation losses may be partially counter balanced by high population growth rates resulting from high food levels. The success of microzooplankton in turbid lakes may also be related to their small size and their ability to avoid predation (Sarma and Nandini, 2007).

For long it has been known that abiotic and biotic factors are important in determining the diversity of zooplankton (Dumont, 1977). Clear lakes dominated by macrophytes are expected to have high species diversity. However, the high species density and diversity of rotifers in the eutrophic, highly contaminated Lake Xochimilco is hard to explain yet well documented (Nandini et al., 2005). One of the factors promoting this condition is perhaps the high fish predation pressure on large zooplankton, thereby reducing the interference competition as well as the high nutrient load and diversity of phytoplankton, which probably reduces the competition for food. The effect of turbidity on fish feeding or demography of a few zooplankton species has been documented based on laboratory works (García-García et al., 2006) but few studies exist on the effect of organic and inorganic turbidity on natural plankton communities (Bilotta and Brazier, 2008; Donohue and Garcia-Molinos, 2009). We studied the effect of turbidity on the community structure of zooplankton in Xochimilco lake, which has high organic and inorganic turbidity throughout the year. The aim of the work was to present data on the seasonal dynamics of zooplankton at two sites in Lake Xochimilco, one channel predominantly with inorganic turbidity (cited as Main Channel hereafter) and the other site, with organic turbidity (Rowing Channel).

\section{Materials and Methods}

Study area : Mexico City was built over an ancient system of five lakes, one of which remains is Lake Xochimilco. The channels of Xochimilco have a surface area of $55,000 \mathrm{~m}^{2}$ and a maximum depth of $1.5 \mathrm{~m}$ (Solís et al., 2006). This water body is eutrophic since it receives effluents from domestic and horticultural wastes. The temperature ranges from 12 to $20^{\circ} \mathrm{C}$, with rains from May to September. For this study, we selected two sampling stations; the first is the Rowing channel $\left(19^{\circ} 16^{\prime} 26.9^{\prime \prime} \mathrm{N} 99^{\circ} 06^{\prime} 17.9^{\prime \prime} \mathrm{W}\right)$ with predominant organic turbidity. This is a small body of water created for rowing and canoeing competitions, but is filled by water from the channels of Xochimilco. The second was the Main channel $\left(19^{\circ} 16^{\prime} 18.2^{\prime \prime} \mathrm{N} 99^{\circ} 06^{\prime} 16.7^{\prime \prime} \mathrm{W}\right)$ with predominant inorganic turbidity, which was near the point at which treated water entered the lake from the 'Cerro de la Estrella' water treatment plant in municipal area Iztapalapa (Mexico City). These sampling stations were at a distance of about one kilometer from each other and are shown in Fig. 1.

Field and laboratory methods : Zooplankton samples were collected every month from June 2013 to May 2014 by filtering 80 $L$ of water from the lake surface in Rowing channel and the Main 


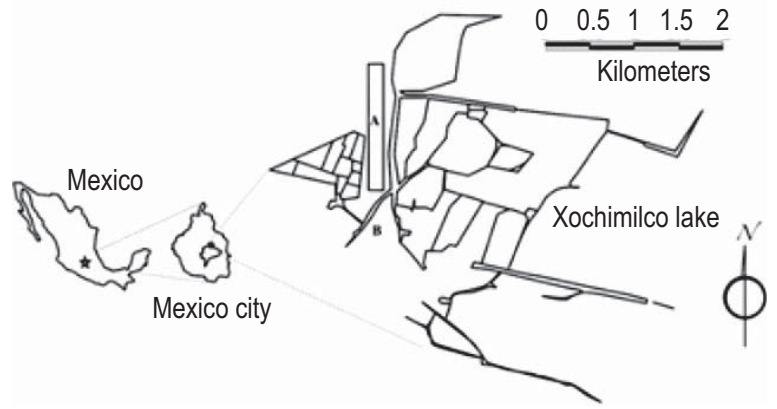

Fig. 1 : Map of Xochimilco Lake. Sampling stations (A) Rowing channel (B) Main channel

channel through a plankton net of $50 \mu \mathrm{m}$ pore size and fixed immediately in $10 \%$ formalin. We measured, in situ or in the laboratory, the following physico-chemical variables: temperature, $\mathrm{pH}$, conductivity and dissolved oxygen using a multi-probe system model YSI 55 (YSI Incorporated, USA). Phosphate-P and nitrate- $\mathrm{N}$ were measured at appropriate wavelengths using a YSI 9100 photometer test kit, transparency (using Secchi disk) and turbidity was measured using a turbidimeter (Hanna, HI 93703).

For zooplankton, we counted three aliquots of $1 \mathrm{ml}$ each of the concentrated samples using an inverted microscope in a Sedgwick Rafter chamber. For rotifers, where needed, we separated the trophi using $10 \%$ sodium hypochlorite solution. For some soft-bodied rotifers, it was necessary to collect live samples and in such cases, we separately collected live zooplankton.

The dominant algal species were identified during this study. The morphological identification of eukaryotic algae and cyanobacteria was made following Komárek et al., 1999; Tavera et al., 2000; Comas et al., 2007 and Tavera and Díez, 2009. For microcrustaceans species we identified and quantified them using a light microscope (Nikon) at different magnifications (10X to $1000 \mathrm{X}$ ). We counted all the individuals in three aliquots of $5 \mathrm{~mL}$ each of the concentrated samples using an inverted microscope. Copepods were classified as nauplii, copepodite and adults; only adult copepods were identified to species. For the taxonomic identification of these crustaceans we used specialized keys (Koste, 1978; Korovochinsky and Smirnov, 1998; Dumont and Negrea, 2002; Elías-Gutiérrez et al., 2008).

In order to measure chlorophyll-a concentration (Chl-a), $250 \mathrm{ml}$ of the water sample was taken and filtered through a Whatman GF/C glass fibre filter within $3 \mathrm{~h}$ of collection. Pigment extraction was extracted using $90 \%$ acetone and concentrations were determined spectrophotometrically (Rice et al., 2012).

Data analysis : Taxonomic data were used for the following analyses: Species diversity was calculated using Shannon-
Wiener diversity index using the following equations (Krebs, 1993):

$$
H^{\prime}=-\sum_{i=1}^{s} P_{i} \log _{2} P_{i}
$$

where, $\mathrm{H}^{\prime}$ is the Shannon-Wiener Index of diversity, $\mathrm{Pi}=$ proportion made up of the $\mathrm{i}^{\text {th }}$ zooplankton species.

The trophic state of the reservoir was determined using ratios based on the number of Brachionus to Trichocerca species $\left(Q_{B / T}\right.$, Sládeček, 1983).

Saprobic indices were calculated using the formula proposed by Pantle and Buck (1955):

$$
S=\Sigma(\mathrm{s} \cdot \mathrm{h}) / \Sigma \mathrm{h}
$$

where, $S$ is the saprobic index, $S$ is the valence of each rotifer (Sládeček, 1983), $\mathrm{h}$ is the relative frequency ( 1 = uncommon, $3=$ common and $5=$ abundant), and the saprobic index (S) takes values on the following ranking scale: 1.0-1.5 = oligosaprobic, $1.6-2.5=\beta$-mesosaprobic, 2.6-3.5= $\alpha$-mesosaprobic and $3.6 \geq$ 4.4 = polysaprobic.

We compared the differences of the environmental variables between each site using paired t-tests. Relationships between the physicochemical and zooplankton data were analysed using the canonical correspondence analysis (CCA) using Canoco for MVSP Shareware 2.0 (Kovachs, 1990). We conducted these analyses on the physicochemical variables tested in the study, which were chlorophyll-a, dissolved oxygen, temperature, $\mathrm{pH}$ and nitrate- $\mathrm{N}$ and phosphate-P concentrations. We incorporated monthly values for the entire 1-year study duration, but we conducted the analyses individually for both the stations. We selected genus level of cladocerans, copepods and rotifers for correspondence analysis. The heterogeneity in the community composition was tested using DCA, the result of the gradient length was 3.0, for which a unimodal method CCA with standardized data was applied. The abundance of data was transformed by $\log (x+1)$ to obtain normal distribution. In Rowing channel, a forward selection of the explanatory variables was used to assess the usefulness of each potential predictor and significant variables were selected. For the Main channel, we used the full model. The statistical significance of variables was tested with partial Monte Carlo permutation test available in the Canoco Software.

\section{Results and Discussion}

Lake Xochimilco is similar to other eutrophic lakes; in spite of the high nutrient loads and the levels of contamination (Solís et al., 2006), high densities and diversity of phytoplankton and zooplankton have been recorded in many previous studies (Nandini et al., 2005; Enríquez et al., 2009; Tavera and Díez, 2009). 
The Rowing channel sampling station was dominated by organic turbidity due to cyanobacterial blooms while turbidity in the Main channel was commonly due to sediment, mostly inorganic particles. Phytoplankton in the former was dominated by cyanobacteria Microcystis spp., (also reported by Arzate Cardenas et al., 2010; Pineda-Mendoza et al., 2011), Planktothrix agardhii (Gomont) Anagnostidis and Komárek 1988, and Golenkinia radiata Chodat 1894, while the Main channel had high densities of the microalgae Desmodesmus sp. Golenkinia radiata, Coelastrum astroideum De Notaris 1867, Pediastrum boryanum (Turpin) Meneghini 1840 and Cyclotella meneghiniana Kützing 1844.

The main difference between the two sampling stations, the Rowing channel and the Main channel was observed in terms of phytoplankton biomass (Chl-a). Although nutrient levels were higher in the Main channel, Chl-a values were highest in the Rowing channel. This is probably due to the high densities of cyanobacteria which are often inedible for zooplankton (AlvaMartinez et al., 2009). Tavera et al. (2000) have shown that cyanobacteria and green chlorococcalean algae were the dominant primary producers in Lake Xochimilco. In the Rowing channel the phytoplankton was dominated by Microcystis. Cyanobacteria are normally less affected by nutrients, especially nitrogen, limitation (Huisman et al., 2005) as was observed in the Rowing channel. The suppression by toxic strains of cyanobacteria may reduce the abundance of rotifers and other zooplankton (Gilbert, 1994). However, we found high densities of the rotifer $B$. havanaensis at this site, probably due to the ability of this species to tolerate Microcystis diets (Alva-Martinez et al., 2009) and the low toxicity of the strain of Microcystis in this water body (Fernandez et al., 2014). In the Main channel, on the other hand, we found Chlorophytes such as Desmodesmus acutus, Golenkinia radiata and Cyclotella meneghiniana, which are known to be better competitors in shallow lakes with high TP concentrations and pH (Jensen et al., 1994).

During this study 51 species of rotifers, 6 species of cladocerans and 2 species of copepods were identified from the lake (Table 1). Rotifers mainly included taxa from two families, Brachionidae and Lecanidae, together accounting for more than half the species richness of rotifers ( 25 species). The species present throughout the year included Brachionus calyciflorus, Brachionus havanaensis, Keratella tropica, Keratella cochlearis, Lecane bulla and Polyarthra vulgaris. Zooplankton densities of most species were higher in the rainy than the dry season. In the rainy season (June to November) we found Keratella tropica to be the most abundant species (800 ind. $\mathrm{I}^{-1}$ ); in the Rowing channel Brachionus havanaensis and Lecane bulla were abundant. In the Main channel higher densities of Brachionus angularis and Euchlanis dilatata were present. In the dry season (February to April) the Rowing channel had high densities of Keratella tropica, Keratella cochlearis and Brachionus havanaensis. Polyarthra vulgaris (140 ind. $\mathrm{I}^{-1}$ ) was the most abundant species, present throughout the study period. In the Main channel we found Brachionus durgae, Lecane bulla and Keratella tropica (Fig. 2). Throughout the year, the densities of most species were higher in summer than in winter. The density of brachionids was lower in the presence of high levels of organic turbidity, which coincides with the presence of high densities of Microcystis, a potentially toxic cyanobacteria. Similar conditions had little effect on the genus Keratella (Fig. 2).

The Shannon-Wiener diversity index ranged between 1.2 to 3.4 in the Main channel, and 1.3 to 2.5 in the Rowing channel; species diversity was significantly lower in the latter (Students $t$ test $=0.019$, df $=11, p<0.05$ ) (Fig. 3). Diversity was higher in August and February in the Main channel and in December in the Rowing channel station (Table 2). The edible algal density and diversity greatly influence the species richness of zooplankton (Wallace et al., 2006). We found lower diversity of rotifers in the Rowing channel, suggesting control from other abiotic or biotic variables between sampling stations. It is likely that the presence of high levels of organic matter reduced the species diversity in the Rowing channel. This could be related to the decrease in the diversity of available food resources.

In the Main channel, which had a greater diversity of green algae, we found a greater richness of rotifer species including Brachionus durgae, Lecane bulla, Keratella tropica as well as the genera Trichocerca, Lepadella, Euchlanis, Mytilina, Platyias and Testudinella, the latter taxa are common in macrophyte-associated habitats (Green, 2003). In the Rowing channel the dominant species are Keratella cochlearis, $K$. tropica, $P$. vulgaris and Brachionus havanaensis. $K$. cochlearis was the third most abundant species that we found throughout the year in higher densities at the Rowing channel station, which suggests that these rotifers are adapted to exploit low-food conditions (Kirk, 2002). These species are generalist feeders with a low threshold food concentration and thus capable of surviving long starvation periods (Kirk, 2002). They are also less susceptible to Microcystis blooms than other rotifers (Alva-Martinez et al., 2007). Another species that we found in high densities in this station was Polyarthra, which was dominant due to its preference for a wider size range of food (approximately 1-40 $\mu \mathrm{m}$ ) (Arndt, 1993) as well as its capacity to avoid predation (Brandl, 2005). Low densities of cladocerans in this lake could be attributed to fish predation (Nandini et al., 2005; Enríquez et al., 2009). The lake supports high densities of carps and tilapia, so much so that these nonnative species are being fished out to provide native species such as the Axolotl (Ambystoma mexicanum) a chance of recovery (Parra-Olea et al., 2012). The rotifers may benefit from high pressure of predation on cladocerans, since it reduces the exploitative and interference competition pressure on them (Hurtado-Bocanegra et al., 2002). Microcrustaceans were dominated by copepods which are more efficient at avoiding fish 

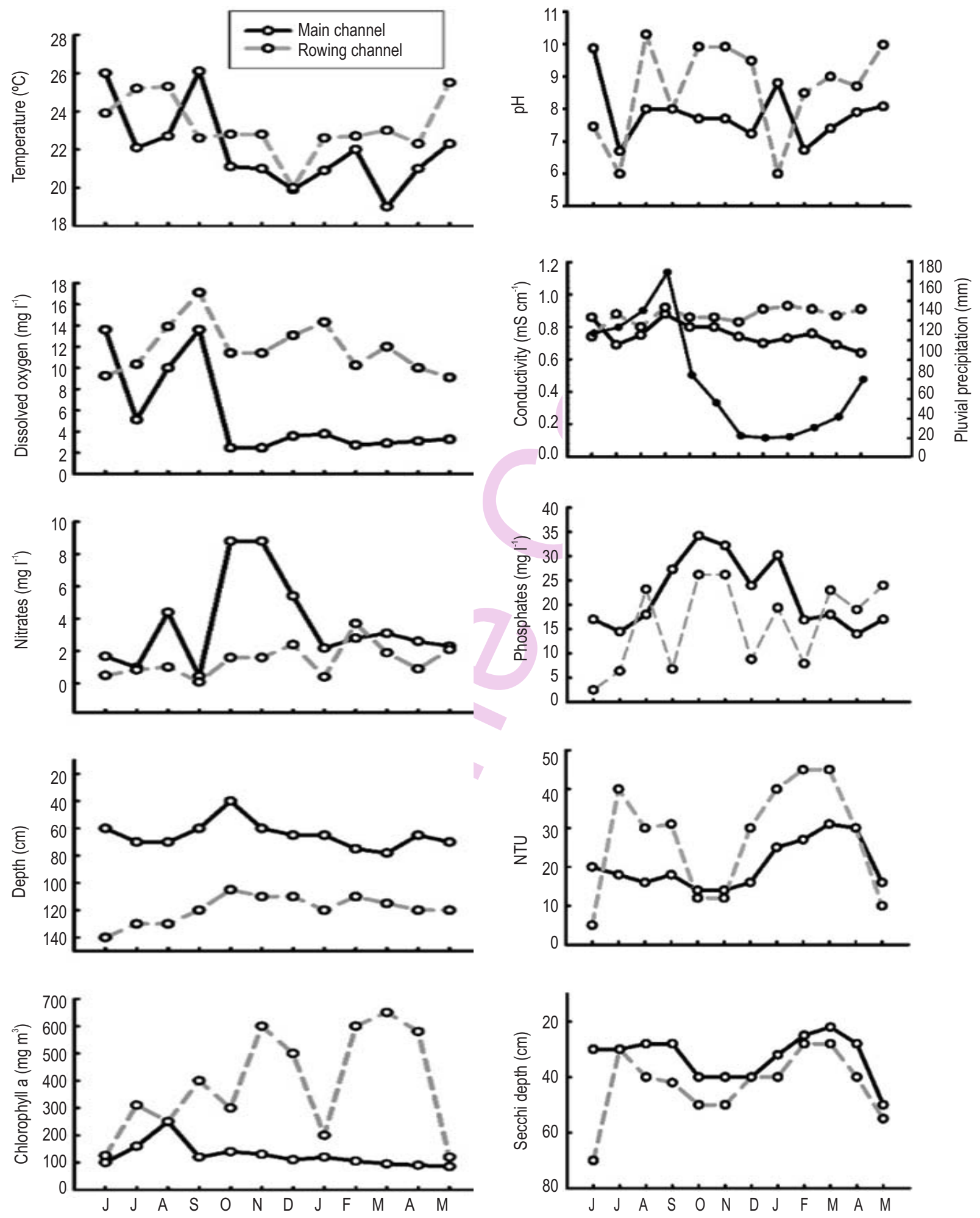

Fig. 2 : Physico-chemical variables over the sampling period (June of 2013 to May of 2014) in Xochimilco Lake. All measurements were taken at two sites: Rowing channel (organic turbidity) and Main channel (inorganic turbidity) 
B. calyciflorus

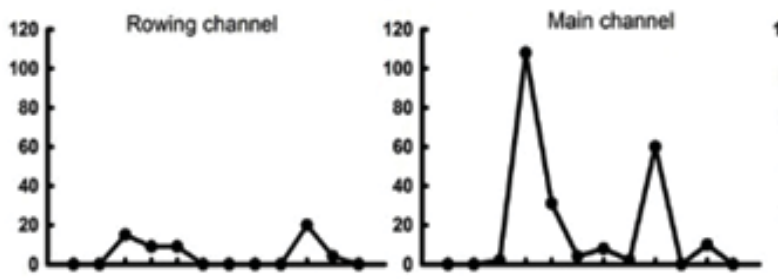

B. angularis
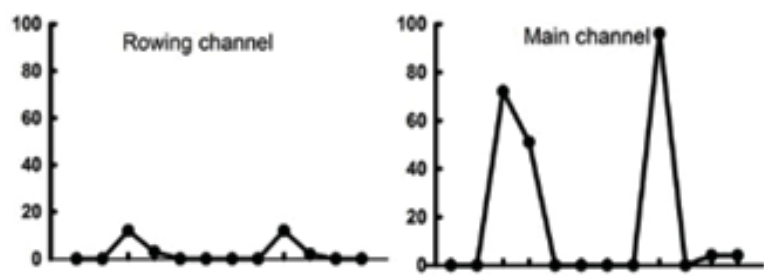

K. tropica

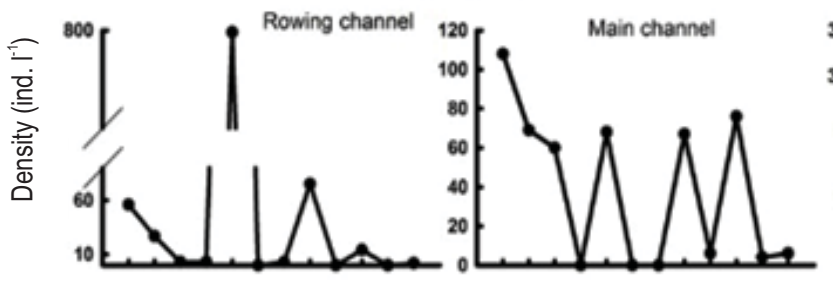

L. bulla

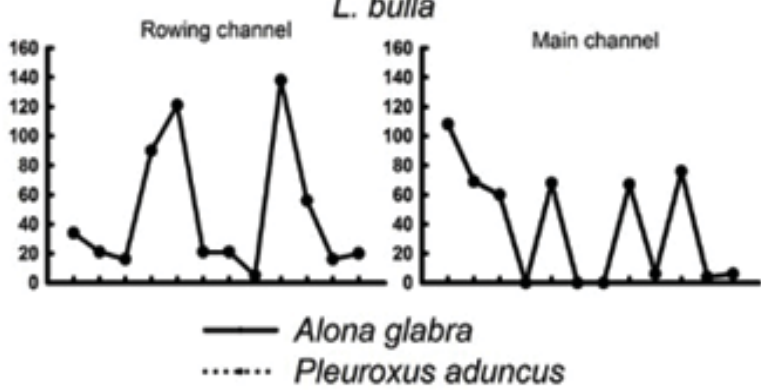

...... Pleuroxus aduncus

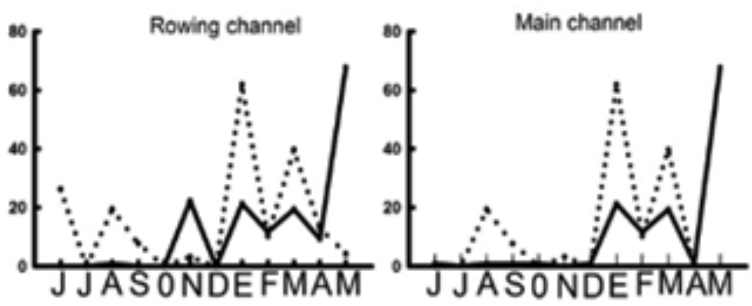

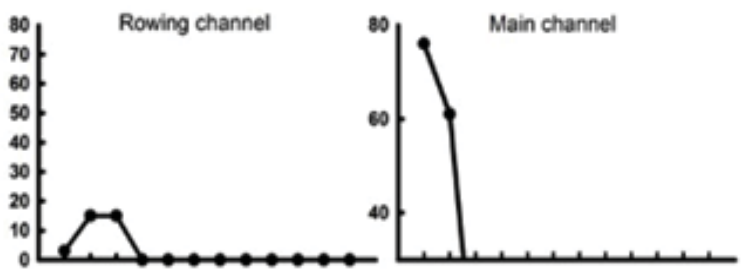

\section{B. havanaensis}

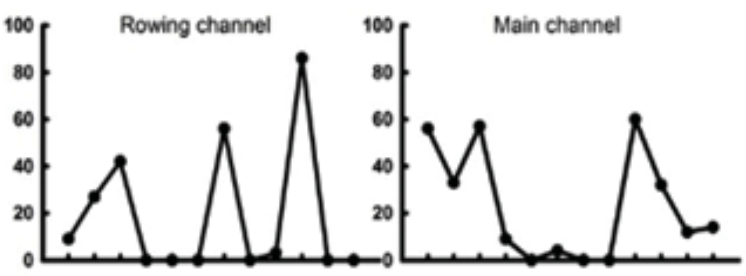

E. dilatata

\section{K. cochlearis}

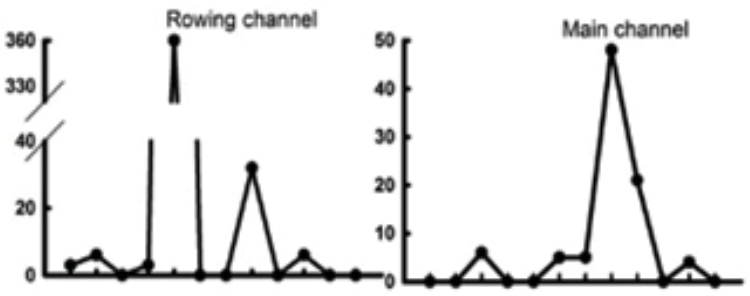

P. vulgaris
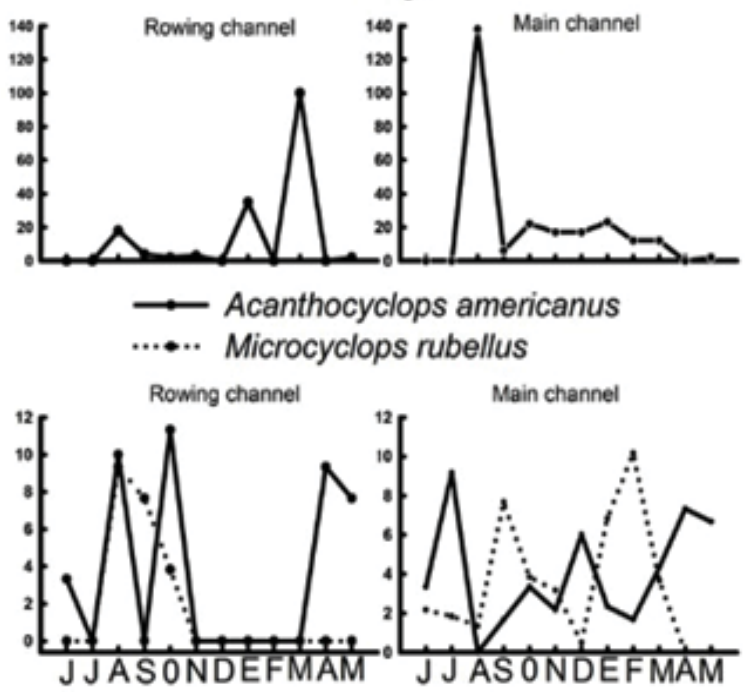

Time (Months)

Fig. 3: Total density of selected zooplankton observed during this study. Shown are mean \pm SD of the densities recorded at two different sites 


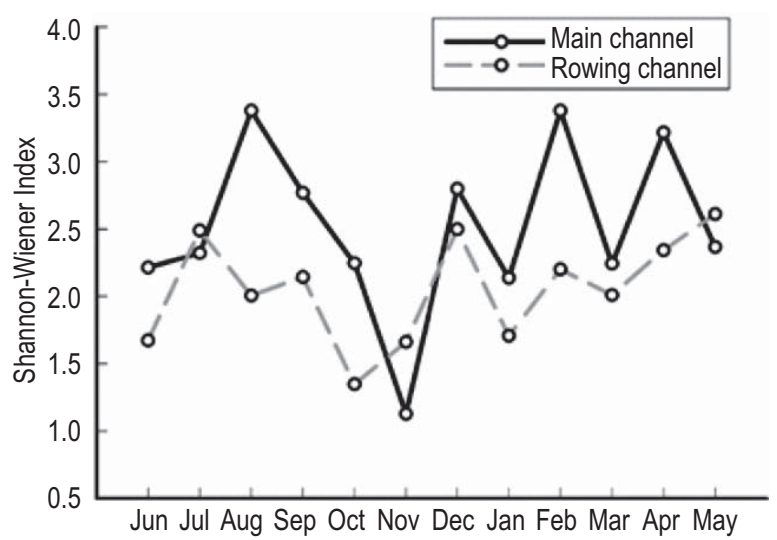

Fig. 4 : Species diversity of zooplankton (Shannon-Wiener index)

(Reid and Williamson, 2010). Though they prey on rotifers (Dussart and Defaye, 2001), in this study there was no significant relationship between copepods and the rotifer density, most probably due to the extremely high rotifer densities, often recorded in this water body (Nandini et al., 2016).

The $Q_{B / T}$ ratio in this lake (both Main channel and rowing canal) was 3.5 (7 species of Brachionus and 2 of Trichocerca; Table 1) affirming the highly eutrophic nature of this water body. All

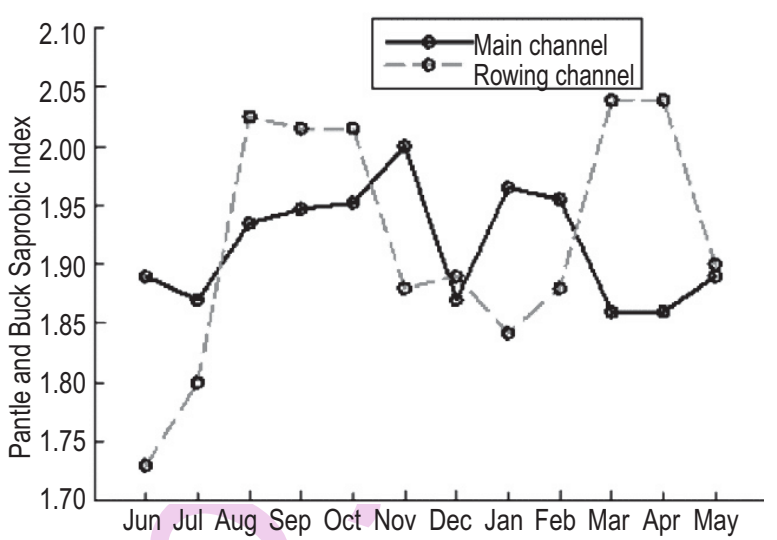

Fig. 5 : Pantle and Buck Saprobic Index at the Rowing channel and Main channel stations over a period of 1 year

species listed are beta-mesosaprobic and alpha-mesosaprobic. The saprobic indices ranged from 1.86 to 2.0 in the Main channel and 1.7 to 2.5 in the Rowing channel station; both sites can be classified as $\beta$-meso-saprobic (Fig. 4). Rotifers are used as indicators of trophic status (Chen et al., 2012) since they have a short life cycle and may respond concurrently to environmental changes. May and O'Hare (2005) opine that rotifer abundances may even be more sensitive indicators of the changes in the trophic state, compared to species composition. Studies

Table 1: Statistical comparisons of the physico-chemical variables between the test sites. Comparisons were made using t-tests or Mann-Whitney Rank sum tests

\begin{tabular}{|c|c|c|c|c|c|c|c|c|}
\hline & Group name & $\mathbf{N}$ & Mean & Std Dev & SEM & $t$ & df & $\mathbf{P}$ \\
\hline \multicolumn{9}{|l|}{ Students t-test } \\
\hline \multirow[t]{2}{*}{ Temp } & $\mathrm{MC}$ & 12 & 22 & 2.15 & 0.62 & -1.59 & 22 & 0.13 \\
\hline & $\mathrm{RC}$ & 12 & 23.22 & 1.55 & 0.44 & & & \\
\hline \multirow[t]{2}{*}{$\mathrm{pH}$} & MC & 12 & 7.84 & 0.86 & 0.25 & -1.53 & 22 & 0.14 \\
\hline & $\mathrm{RC}$ & 12 & 8.6 & 1.49 & 0.43 & & & \\
\hline \multirow[t]{2}{*}{ Secchi Depth } & MC & 12 & 42.75 & 12.15 & 3.51 & 2.37 & 33 & 0.03 \\
\hline & $\mathrm{RC}$ & 12 & 32.75 & 8.058 & 2.32 & & & \\
\hline \multirow[t]{2}{*}{ Conduct. } & $\mathrm{MC}$ & 12 & 0.75 & 0.071 & 0.02 & & & \\
\hline & $\mathrm{RC}$ & 12 & 0.86 & 0.056 & 0.016 & -4.38 & 22 & 0.001 \\
\hline \multirow[t]{2}{*}{ Depth } & MC & 12 & 119.16 & 10.18 & 2.94 & & & \\
\hline & $\mathrm{RC}$ & 12 & 64.83 & 9.74 & 2.81 & 13.35 & 22 & 0.001 \\
\hline \multicolumn{9}{|c|}{ Mann-Whitney Rank Sum Test } \\
\hline \multirow[t]{3}{*}{ Dissolved oxygen } & Group & $\mathrm{N}$ & Median & $25 \%$ & $75 \%$ & 98.5 & 12 & 0.003 \\
\hline & MC & 12 & 3.41 & 2.82 & 7.55 & & & \\
\hline & $\mathrm{RC}$ & 12 & 11.4 & 10.1 & 13.48 & & & \\
\hline \multirow[t]{3}{*}{ Chlorophyll-a } & Group & $\mathrm{N}$ & Median & $25 \%$ & $75 \%$ & 222 & 12 & 0.001 \\
\hline & $\mathrm{MC}$ & 12 & 690 & 475 & 925 & & & \\
\hline & $\mathrm{RC}$ & 12 & 115 & 97.5 & 135 & & & \\
\hline \multirow[t]{2}{*}{ Phosphates } & MC & 12 & 18 & 17 & 28.75 & 17.5 & 12 & 0.24 \\
\hline & $\mathrm{RC}$ & 12 & 19.2 & 7.35 & 23.6 & & & \\
\hline \multirow[t]{2}{*}{ Nitrates } & MC & 12 & 2.7 & 1.93 & 4.9 & 194 & 12 & 0.01 \\
\hline & $\mathrm{RC}$ & 12 & 1.3 & 0.67 & 2 & & & \\
\hline \multirow[t]{2}{*}{ NTU } & MC & 12 & 18 & 16 & 26 & 131 & 12 & 0.28 \\
\hline & $\mathrm{RC}$ & 12 & 30 & 12 & 40 & & & \\
\hline
\end{tabular}


Table 2 : List of zooplankton species recorded in Xochimilco from June 2013 to July 2014. "+" indicates the presence of a given zooplankton species in the Rowing channel, "x" for the Main channel and (-) indicates absence of a given species.

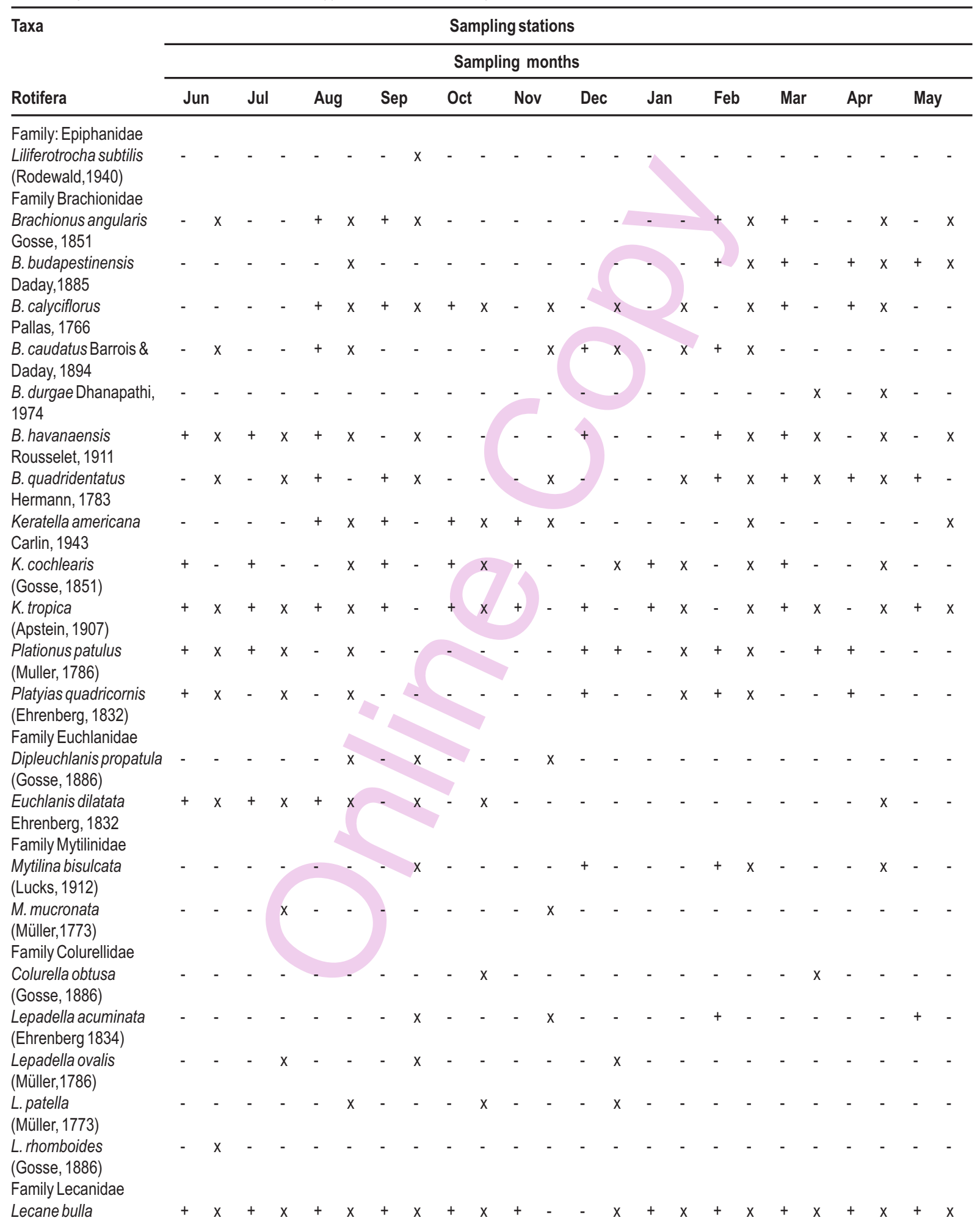


(Gosse, 1851)

L. closterocerca

(Schmarda, 1859)

L. elegans Harring, 1914

L. flexilis (Gosse, 1886)

L. hamata (Stokes, 1896)

L. inermis (Bryce,1892)

L. ludwigii

(Eckstein, 1883)

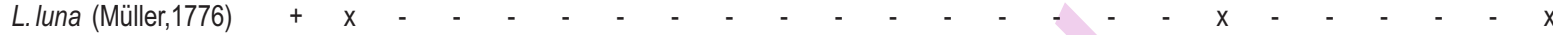

L. curvicornis

(Murray, 1913)

L. obtusa (Murray,1913)

L. ohioensis

(Herrick, 1885)

L. pyriformis

(Daday, 1905)

L. quadridentata

(Ehrenberg, 1830)

L. stokesii(Pell, 1890)

L. unguitata

(Fadeev, 1925)

Family: Lindiidae

Lindia torulosa

Dujardin, 1841

Family Notommatidae

Cephalodella catellina

(Müller,1786)

Cephalodella gibba

(Ehrenberg, 1830)

Family Trichocercidae

Trichocerca bicristata

(Gosse, 1887)

T. tenuior (Gosse, 1886)

Family Synchaetidae

Polyarthra vulgaris

Carlin, 1943

Family Asplanchindae

Asplanchna brightwellii

Gosse, 1850

A. sieboldii

(Leydig, 1854)

Family Dicranophoridae

Dicranophorus forcipatus -

(Müller,1786)

Order Gnesiotrocha

Family Testudinellidae

Testudinella patina

(Hermann, 1783)

Testudinella mucronata

(Gosse, 1886)

Family Filiniidae

Filinia cornuta

(Weisse,1847)

F. longiseta

(Ehrenberg, 1834)

F. terminalis

(Plate, 1886)

Cladocera 


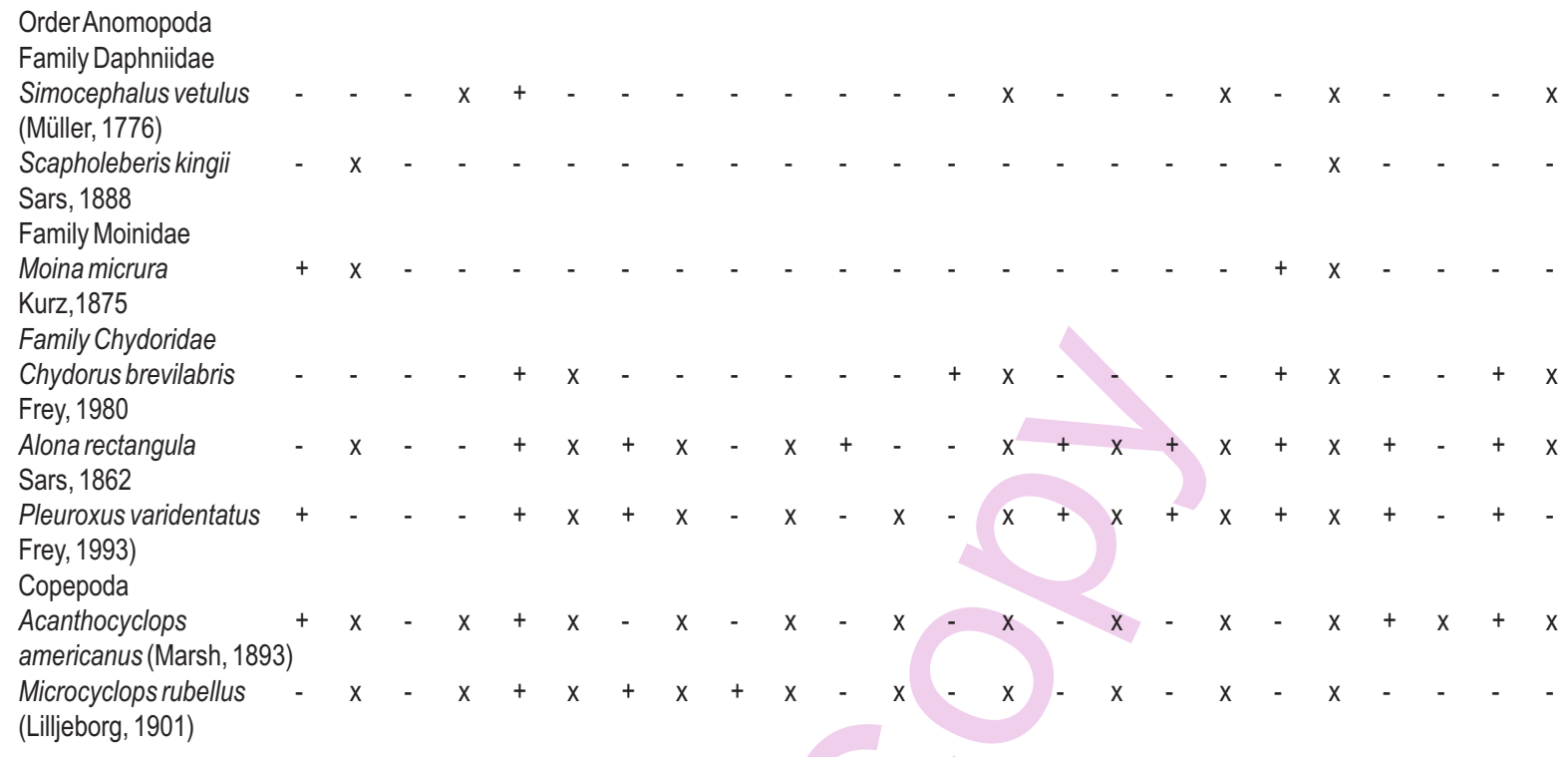

describing the relationship between trophic status and the rotifer community index, are reliable in several water bodies (Duggan et al., 2001). Another way to classify the trophic status of a

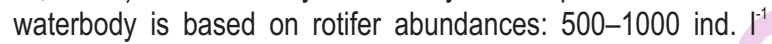

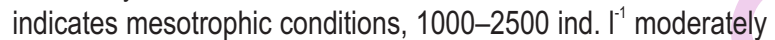
eutrophic and 3000-4000 ind. I $^{-1}$ eutrophic (May and O'Hare, 2005; Wen et al., 2011). Our results for the most abundant species fall within the range of eutrophic levels. On the other hand, indices using rotifers, such as the saprobic index and $Q_{B / T}$ (Sládeček, 1983) indicate that the water body is eutrophic. Our results for the most abundant species fall within the range of eutrophic levels. Furthermore, a diversity of aquatic environments, such as channels with different physicochemical variables, high turbidity and macrophytes, may provide more niches and microhabitats as well refuge against predators to rotifers which according to the intermediate disturbance hypothesis (Connell, 1978) should promote biodiversity. The average species diversity of zooplankton in the lake varied between 1.2 and 3.5; this range was recorded in other high altitude waterbody in Mexico (Ramírez-García et al., 2002; Nandini et al., 2008) previously also in Xochimilco (Nandini et al., 2005; Enríquez et al., 2009). These values indicate that the lake was mesotrophic.

Data on the physicochemical analyses are presented in Fig. 5. Water temperature during the study period ranged from 19 to $26^{\circ} \mathrm{C}$. The $\mathrm{pH}$ values were often highly alkaline for the Rowing channel while in the Main channel they were neutral in almost all cases with values less than 9 . We also observed a generally lower and less fluctuating $\mathrm{pH}$ values in the Main channel compared to the Rowing channel. Dissolved oxygen (DO) concentrations ranged from 9.0 to $>17.0 \mathrm{mg} \mathrm{L}^{-1}$ for the Rowing channel and from 2 to $5 \mathrm{mg} \mathrm{L}^{-1}$ for the Main channel site during most of the study period except for occasional peaks of 10-14 $\mathrm{mg} \mathrm{l}^{-1}$. High level of dissolved oxygen has been reported in water bodies with algal blooms (Nandini et al., 2016). Secchi transparency levels were usually between 0.2 and $0.5 \mathrm{~m}$, which often represented $50 \%$ of the total depth which ranged from 0.45 to $0.60 \mathrm{~m}$. For the Main channel, levels were between 0.30 to $0.50 \mathrm{~m}$ and represented $30 \%$ of the total depth. These were 1.20 to $1.40 \mathrm{~m}$ for a Rowing channel (Fig. 2). The chlorophyll-a concentration ranged from 350 to $1200 \mathrm{\mu g} \mathrm{l}^{-1}$ in the Rowing channel and between 50-350 $\mathrm{g} \mathrm{Il}^{-1}$ in the Main channel; it was significantly higher in the former site throughout the study period (Student's $t$ test $=6.30, \mathrm{df}=11, \mathrm{p}$ $<0.001$ ). The turbidity was similar at both sites, ranging between 5-45 NTU in the Rowing channel and between 5-30 NTU in the Main channel; it was frequently higher at the former site (Fig. 2). Significant differences were observed between the study sites in Secchi depth, conductivity, depth, dissolved oxygen and chlorophyll-a ( $p<0.05$; Students t-test or Mann Whitney test, Table 2). The concentration of nitrate- $\mathrm{N}$ varied from 0.2 to $4 \mathrm{mg} \mathrm{l}^{-1}$ but in October and December reached up to $9 \mathrm{mg} \mathrm{l}^{-1}$. Phosphate-P varied from 18 to $19.2 \mathrm{mg} \mathrm{l}^{-1}$ (5.94 to $6.33 \mathrm{mg} \mathrm{l}^{-1}$ of Phosphorous). However, according to the concentrations of the nutrients Xochimilco is a hypertrophic lake with nitrogen and phosphorus levels close to the maximal permissible limits (The OECD model suggests threshold of $0.035 \mathrm{mg} \mathrm{I}^{-1} \mathrm{Ph}$ osphorus concentrations for eutrophic lakes (Tavera and Díez, 2009; USEPA, 2010). Annual mean total phosphorus concentration in excess of only $0.02 \mathrm{mg} \mathrm{l}^{-1}$ may trigger eutrophication in some lakes (Mainstone and Parr, 2002). 


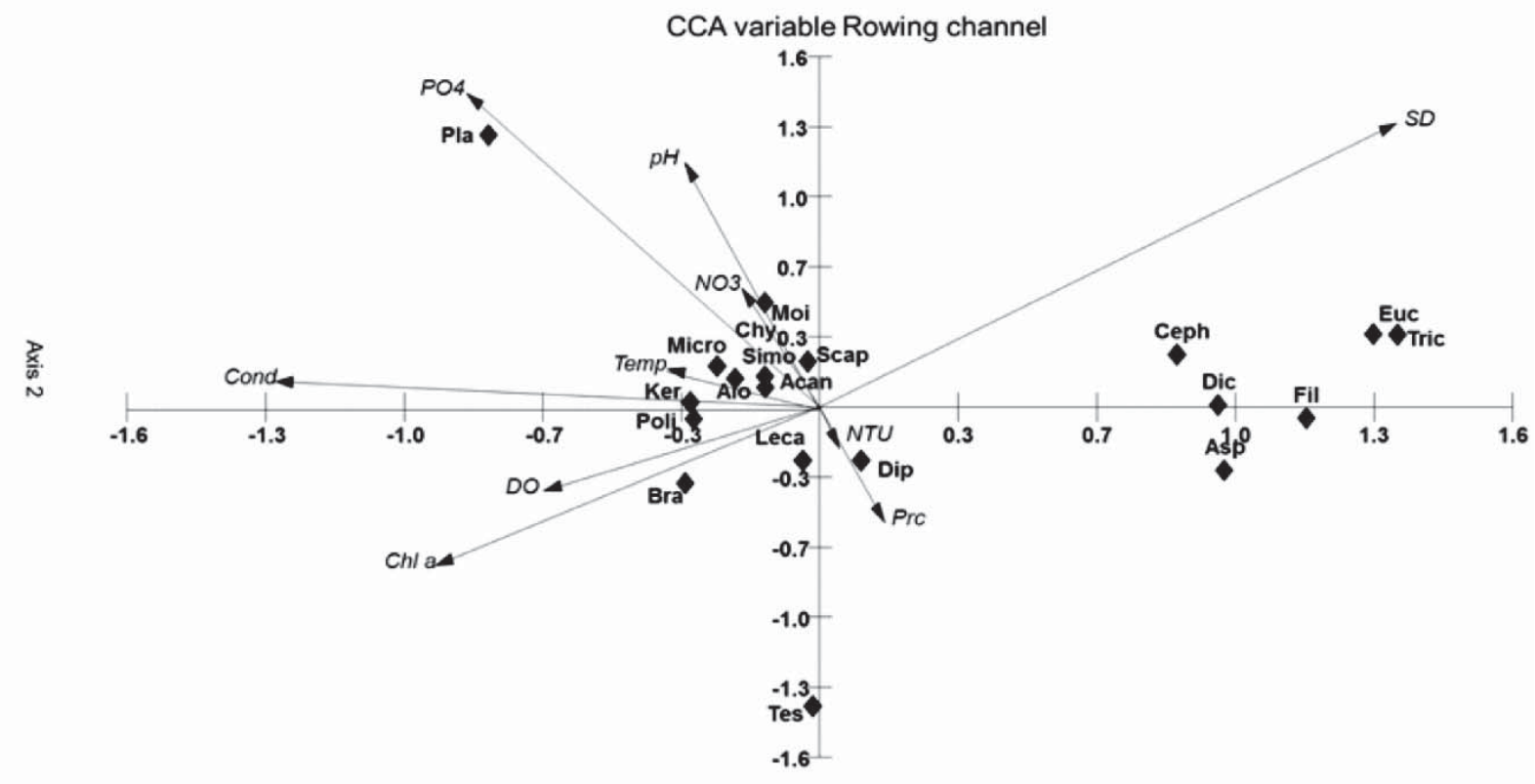

Vector scaling: 2.10

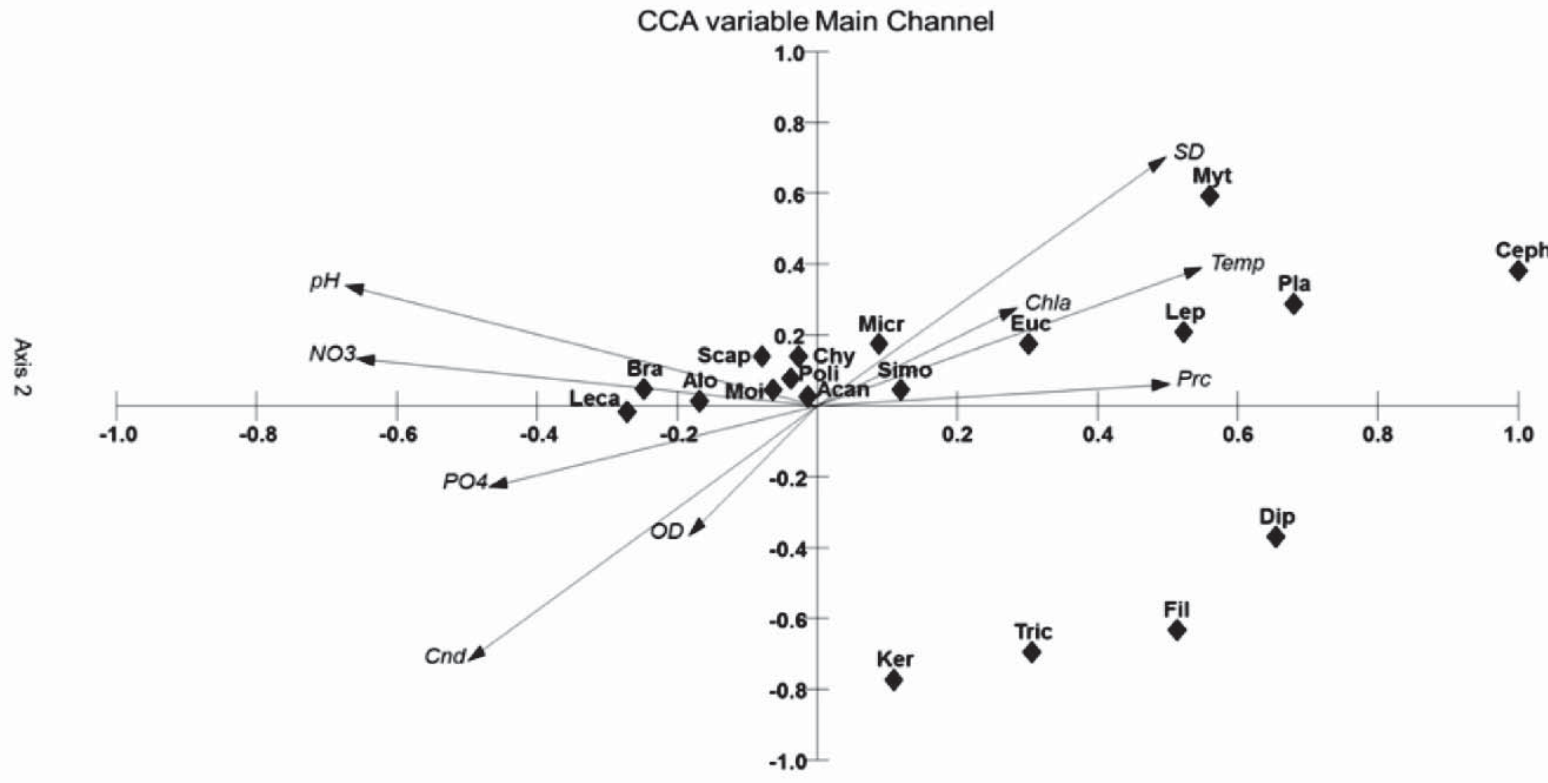

Vector scaling: 1.29

Axis 1

Fig. 6 : Canonical Correspondence Analysis between rotifers cladocerans, copepods and environmental variables in the (a) Rowing channel and (b) Main channel. Abbreviations of environmental variables are: temperature (Temp); pH, dissolved oxygen (DO), nitrate-N (N03), and phosphate-P (P04), Secchi disc (SD), Precipitation (Prc), Chlorophyll-a (CLA). The Genera included are: Brachionus (Bra); Keratella (Ker); Lecane (Leca); Polyarthra (Poly); Platyias (Pla). Dipleuchlanis (Dip), Euchlanis (Euch); Mytilina (Myt); Colurella (Col); Lepadella (Lep); Cephalodella (Ceph); Trichocerca (Tri); Asplanchna (Asp); Dicranophorus (Dicra); Testudinella (Tes); Filinia (Fil); Simocephalus (Simo); Scapholeberis (Sca); Moina (Moi); Chydorus (Chy); Alona (Alo); Chydorus (Chy); Acanthocyclops (Aca); Microcyclops (Micro) 
In our study, we observed that high turbidity adversely affected the cladocerans more than the rotifers, evident in the CCA analyses. Our canonical correlation analyses (CCA) also indicates that most taxa are ordinated based on the level of nutrients, more so in the Rowing channel than the Main channel. The phosphorus levels in the Main channel, correspond to hypertrophic conditions, but this is not corroborated by the chlorophyll concentrations; a trend also reported in the Chimaliapan wetland (García-García et al., 2012). However, the Main channel shows an inverse relation between nutrients and chlorophyll. This could be due to the high density of macrophytes at this site, which shade out phytoplankton production regardless of an abundance of nutrients (Cozar et al., 2007). Such conditions also promote the growth of Microcystis spp. which can avoid the high light intensity and move up to the water surface, when underwater light conditions are poor (Brookes and Ganf, 2001).

The canonical correspondence analysis (CCA) in the Rowing channel station, showed that the first two ordination axes explained $46 \%$ of the variance of the species data in CCA (Fig. 6a). The eigenvalues for the first two axes are 0.062 and 0.085 . The first and second axes are well correlated with the environmental data ( $r=99.5$ and $r=93.6)$. The Monte Carlo permutation test was significant on the first axis $(F=2.92, P=$ 0.02). Only the variable Secchi disc was significant. This variable explains the distribution of species. However, we have decided to show the graph with all variables to indicate trends. There was a clear inverse relation between Secchi depth and Chlorophyll-a concentration in the Rowing channel during the study period. Nutrients (Nitrate- $\mathrm{N}$ and Phosphate-P) were negatively correlated with the rainfall (precipitation). The cladocera and copepod genera as well as the rotifers Brachionus, Keratella and Polyarthra formed clusters in regions representing high productivity (low Secchi transparency or high Chlorophyll-a) and high turbidity.

For the Main channel the CCA showed that the first two ordination axes explained $48 \%$ of the variance of the species data (Fig. 6b). The eigen values for the first two axes are 0.20 and 0.15 . The Monte Carlo permutation test was not significant $(F=0.40, P$ $=0.56)$. For this station, also we performed forward selection but it was not significant. Observation of their general distribution suggests that there is a continuous variation of the species composition in the whole data set and therefore we were unable to find distinct clusters in the data set. As at the previously analyzed site, the cladocerans were associated with high productivity while the rotifers, Brachionus and Polyarthra were more correlated to high Nitrate-N levels and $\mathrm{pH}$.

In Lake Xochimilco, the zooplankton community was dominated by rotifers; cladocerans and copepods were few, as was found in previous studies. This lake has the characteristics of a eutrophic water-body, with a dominance of rotifer genera such as Keratella, Brachionus, Polyarthra with the highest densities.
Our study shows that organic turbidity had an adverse effect as compared to inorganic turbidity on zooplankton density and diversity. This has a widespread impact considering the increasing levels of contamination of freshwater ecosystems worldwide.

\section{Acknowledgments}

One of us (M.A.G.M.) thank the Mexican Council for Science and Technology (CONACyT-211276) for doctoral scholarship and Instituto Politécnico Nacional, ENCB for additional help. SN and SSSS thank PAPIIT (UNAM) (IN213413 and IN216315) for financial assistance.

\section{References}

Alva-Martínez, A.F., S.S.S. Sarma and S. Nandini: Effect of mixed diets (cyanobacteria and green algae) on the population growth of the cladocerans Ceriodaphnia dubia and Moina macrocopa. Aquatic. Ecol., 41, 579-585 (2007).

Alva-Martínez, A.F., R. Fernández, S.S.S. Sarma and S. Nandini: Effect of mixed toxic diets (Microcystis and Chlorella) on the rotifers Brachionus calyciflorus and Brachionus havanaensis cultured alone and together. Limnologica,39, 302-305 (2009).

Arndt, $\mathrm{H}$. : Rotifers as predators on components of the microbial web (bacteria, heterotrophic flagellates, ciliates) a review. Hydrobiologia, 255, 231-246 (1993).

Arzate-Cárdenas, M., R. Olvera-Ramírez and F. Martínez-Jerónimo: Microcystis toxigenic strains in urban lakes: A case of study in Mexico City. Ecotoxicol., 19, 1157-1165(2010).

Bilotta, G. S. and R. E. Brazier: Understanding the influence of suspended solids on water quality and aquatic biota. Water Res., 42, 2849-2861 (2008).

Brandl, Z.: Freshwater copepods and rotifers: predators and their prey. Hydrobiologia, 546, 475-489 (2005).

Brookes, J.D. and G.G. Ganf: Variations in the buoyancy response of Microcystis aeruginosa to nitrogen, phosphorus and light. J. Plankton Res., 23, 1399-1411 (2001).

Chaparro-Herrera, D.J., S. Nandini, S.S.S. Sarma and L. Zambrano: Feeding behavior of larval Ambystoma mexicanum. AmphibiaReptilia, 32, 509-517 (2011).

Chen, L., Q. Liu, Z. Peng, Z. Hu, Z. Xue and W. Wang: Rotifer community structure and assessment of water quality in Yangcheng Lake. Chin. J. Oceanol. Limnol., 30,47-58 (2012).

Comas, A., E. Novelo and R. Tavera: Coccal green algae (Chlorophyta) in shallow ponds in Veracruz, México. Arch. Hydrobiol. Suppl. Algol. Stud., 124, 29-69 (2007).

Connell, J.H.: Diversity in tropical rain forests and coral reefs. Science, 199, 1302-1310 (1978).

Cózar, A., N. Bergamino, S. Mazzuoli, N. Azza, L. Bracchini, A.M. Dattilo and S.A. Loisell: Relationships between wetland ecotones and inshore water quality in the Ugandan coast of Lake Victoria. Wetlands Ecol. Manage., 15, 499--507 (2007).

Declerck, S., J. Vandekerkhove and L. Johansson: Multi-group diversity in shallow lakes along gradients of phosphorus and water plant cover. Ecology, 86, 1905-1915(2005).

Descy, J.P., C.S. Reynolds and J. Padisák: Phytoplankton in turbid environments: Rivers and shallow lakes. Springer Science \& 
Business Media. Boston, London (2013).

Donohue, I. and J. Garcia-Molinos: Impacts of increased sediment loads on the ecology of lakes. Biological Rev., 84, 517-531 (2009).

Duggan, I.C., J.D. Green and R.J. Shiel: Distribution of rotifers in North Island, New Zealand, and their potential use as bioindicators of lake trophic state. Hydrobiologia, 446, 155-164 (2001).

Dumont, H.J.: Biotic factors in the population dynamics of rotifers. Arch. Hydrobiol. Beih. Ergebn. Limnol., 8, 98-122 (1977).

Dumont, H.J. and S.V. Negrea: Introduction to the class Branchiopoda. Guides to the identification of the microcrustaceans of the continental waters of the world 19. Leyden: Backhyus Publishers, The Netherlands (2002).

Dussart, B.H. and D. Defaye: Introduction to the Copepoda. Backhuys Publishers, Leiden (2001).

Enríquez, G.C., S. Nandini and S.S.S. Sarma: Seasonal dynamics of zooplankton in Lake Huetzalin, Xochimilco (Mexico City, Mexico). Limnologica, 39, 283-291 (2009).

Elías-Gutiérrez, M.E., M. Suárez-Morales, M. Gutiérrez-Aguirre, M. Silva-Briano, J.G. Granados-Ramírez and T.G. Garfias-Espejo: Guía ilustrada de los microcrustáceos (Cladocera y Copepoda) de aguas continentales de México. Universidad Nacional Autónoma de México, México (2008).

Fernández, R., S. Nandini, S.S.S. Sarma and M.E. Castellanos-Páez: Effects of cyanobacteria, fish kairomones, and the presence of ostracods on the demography of Simocephalus vetulus (Cladocera). Invertebr. Biol., 133, 371-380 (2014).

García-García, G., S. Nandini and S.S.S. Sarma: Turbidity mitigates lead toxicity to cladocerans (Cladocera). Ecotoxicology, 15, 425-436 (2006).

Garcia-Garcia, G., S. Nandini, S.S.S. Sarma, F. Martínez-Jerónimo and J.Jiménez-Contreras: Impact of chromium and aluminum pollution on the diversity of zooplankton: A case study in the Chimaliapan wetland (Ramsar site) (Lerma basin, Mexico). J. Environ. Sci. Hlth., PartA, 47, 534-547 (2012).

Green, J.: Associations of planktonic and periphytic rotifers in a tropical swamp, the Okavango Delta, Southern Africa. Hydrobiologia, 490, 197-209 (2003).

Huisman, J., H.C.P. Matthijs and P.M. Visser: Harmful cyanobacteria. Springer-Verlag, Berlin, Germany (2005).

Hurtado-Bocanegra, M.D., S. Nandini and S.S.S. Sarma: Combined effects of food level and inoculation density on competition between Brachionus patulus (Rotifera) and the cladocerans Ceriodaphnia dubia and Moina macrocopa. Hydrobiologia, 468, 13-22 (2002).

Jensen, J.P., E. Jeppesen, K. Olrik and P. Kristensen: Impact of nutrients and physical factors on the shift from cyanobacterial to chlorophyte dominance in shallow Danish lakes. Can. J. Fish. Aquat. Sci., 51, 1692-1699(1994).

Kirk, K.L. and J.J. Gilbert: Suspended clay and the population dynamics of planktonic rotifers and cladocerans. Ecology, 71, 1741-1755 (1990).

Kirk, K.L.: Competition in variable environments: Experiments with planktonic rotifers. Freshwater Biol., 47, 1089-1096 (2002).

Lövstedt, C.B. and L. Bengtsson: The role of non-prevailing wind direction on resuspension and redistribution of sediments in a shallow lake. Aquatic Sci., 70, 304-313 (2008).

Koste, W.: Rotatoria. Die Rädertierte Mittleleuropas. Gebruder Borntraeger, Berlin, Stuttgart (1978).

Kovachs, W.L.: MultiVariate Statistical Package. MVSP Shareware 2.0.
Kovach Comput Serv. Pentraeth, Wales. www.kovcomp.co.uk/ mvsp3man.pdf January of 2015 (1990).

Krebs, J.R.: Ecological Methodology. Harper Collins Publ., New York (1993).

Levine, S.N., R.F. Zehrer and C.W. Burns: Impact of resuspended sediments on zooplankton feeding in Lake Waihola, New Zealand. FreshwaterBiol., 50, 1515-1536 (2005).

Mainstone, C.P. and W. Parr: Phosphorus in rivers-ecology and management. Sci. Total Environ., 282, 25-47(2002).

Martínez-Arroyo, A. and E. Jáuregui: On the environmental role of urban lakes in Mexico City. Urban Ecosyst., 4, 145-66 (2000).

May, L. and M. O' Hare: Changes in rotifer species composition and abundance along a trophic gradient in Loch Lomond, Scotland, UK. Hydrobiologia, 546, 397-404 (2005).

Nandini, S., P. Ramírez-García and S.S.S. Sarma: Seasonal variations in the species diversity of planktonic rotifers in Lake Xochimilco, Mexico.Freshwater Ecol., 20, 287-294 (2005).

Nandini, S., M. Merino-Ibarra and S.S.S. Sarma: Seasonal changes in the zooplankton abundances of the reservoir Valle de Bravo (State of Mexico, Mexico). Lake Reserv. Manage., 24, 321-330 (2008).

Nandini, S., P. Ramírez-García and S.S.S. Sarma: Water quality indicators in Lake Xochimilco, Mexico: zooplankton and Vibrio cholera. J. Limnol., 75, 91-100 (2016).

Parra-Olea, G., K.R. Zamudio, E. Recuero, X. Aguilar-Miguel, D. Huacuz and L. Zambrano: Conservation genetics of threatened Mexican axolotls (Ambystoma). Anim. Conserv., 15, 61-72 (2012).

Pineda-Mendoza, R., F. Martínez-Jerónimo, G. Garduño-Solórzano and R. Olvera-Ramírez: Caracterización morfológica y molecular de cianobacterias filamentosas aisladas de florecimientos de tres lagos urbanos eutróficos de la ciudad de México. Polibotánica, 31, 31-50 (2011).

Ramírez, G.P., S. Nandini, S.S.S. Sarma, V.E. Robles, I. Cuesta and M.D. Hurtado: Seasonal variations of zooplankton abundance in the fresh water reservoir Valle de Bravo (México). Hydrobiologia, 467, 99-108 (2002).

Reid, J.W. and C.E. Williamson: Copepoda, In: Ecology and classification of North American freshwater invertebrates. (Eds. J.H. Thorp and A.P. Covich). Academic Press, Burlington (2010).

Rice, E.W., R.B. Baird, A.D Eaton and L.S. Clesceri: Standard Methods for the Examination of Water and Wastewater. $22^{\text {nd }}$ Edn., American Water Works Association/American Public Works Association/ Water Environment. Washington D. C. (2012).

Sarma, S.S.S. and S. Nandini: Small prey size offers immunity to predation: A case study on two species of Asplanchna and three brachionid prey (Rotifera). Hydrobiologia, 593, 67-76 (2007).

Sladecek, V.: Rotifers as indicators of water quality. Hydrobiologia, 100, 169-201 (1983).

Solís, C., J. Sandoval, H. Pérez-Vega and M. Mazari-Hiriart: Irrigation water quality in southern Mexico City based on bacterial and heavy metal analyses. Nucl. Instrum. Methods, 249, 592-595 (2006).

Tavera, R., E. Novelo and A. Comas: Chlorococcalean algae (s.l.) from the Ecological Park of Xochimilco, Mexico. Arch. Hydrobiol Suppl. Algol. Stud., 100, 65-94 (2000).

Tavera, R. and B. Díez: Multifaceted approach for the analysis of the phototrophic microbial community in a freshwater recreational area of Xochimilco, Mexico. Hydrobiologia, 636, 353-368 (2009).

U.S. Environmental Protection Agency (EPA): Washington, DC. "List of Contaminants and their MCLs."http://water.epa.gov/drink/ contaminants/upload/mcl-2.pdf(2010). 
Vasconcelos, V.M.: Eutrophication, toxic cyanobacteria and cyanotoxins: when ecosystems cry for help. Limnetica, 25, 425-432 (2006).

Wallace, R.L., T.W. Snell, C. Ricci and T. Nogrady: Rotifera: Biology, Ecology and Systematics. Backhuys Publisher, The Hague, The Netherlands (2006).

Wen, X., Y. Xi, F. Qian, G. Zhang and X. Xiang: Comparative analysis of rotifer community structure in five subtropical shallow lakes in East China: Role of physical and chemical conditions. Hydrobiologia, 661, 303-316 (2011).

Zambrano, L. and E. Valiente: Mitigación del impacto de las especies introducidas en la zona lacustre de Xochimilco. Gobierno del Distrito Federal, Instituto de Biología de la UNAM, Mexico (2008). 